\title{
特集 阪神・淡路大震災復興の不動産学的研究
}

\section{分科会報告}

\section{被災者向け住宅供給としての特定優良賃貸 住宅の役割とその問題点について}

難波 里美*

\section{1.はじめに}

特定優良賃貸住宅は, 平成 5 年に施工された「特 定優良賃貸住宅の供給の促進に関する法律」(平成 5 年法律第52号)に基づき供給される住宅で，阪 神・淡路大震災後被災市においては，住宅復興の 一手法として建設基準を緩和し，積極的に活用し ている。

本稿では，各自治体の特定優良賃貸住宅の被災 者向け住宅としての取り組みとその制度上の問題 点について明らかにする。

\section{2 . 特定優良貸貸住宅の定義・事業の仕組}

特定優良賃貸住宅とは，特定優良賃貸住宅の供 給の促進に関する法律(平成 5 年法律第 52 号。以下 「法」という。）に基づき，民間の土地所有者等が新 たに建設した賃貸住宅を市・住宅供給公社等の管 理者が一定期間借り上げ若しくは管理受託すると ともに，市と国がその建設費及び家貨について補 助を行う中堅所得者層向けの居住環境が良好な賃 貸住宅をいう。(以下, 特優賃住宅と略する。)

その事業の仕組み・概要は兵庫県・神戸市を例

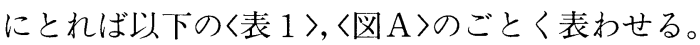

\section{3. 被災した自治体での特定優良貨貸住宅 の制度比較}

〈表 $2 〉 は ，$ 被災した自治体での特定優良賃貸 住宅の取組みと制度をまとめたものである。

建設基準の項目では，兵庫県については阪神大 震災以前の従来制度について括弧書きにした。

神戸市，西宮市，芦屋市の敷地規模，総戸数に ついては，一定の場合に緩和される基準を記載し た。また，自治体の特優賃住宅の認定基準と，主 要な管理主体(一括借上を主としている住宅供給公 社等)の基準とが異なる場合は, 原則自治体の認定 基準を優先させ，公社等の例外もあわせて記載す るようにしている。

この制度比較では, 被災した自治体は, 復興住 宅供給手段として特優賃住宅を採用しており，神 戸市の5,700戸を筆頭に西宮市1,300戸, 尼崎市500 戸，宝塚市350戸，芦屋市300戸，川西市，伊丹市 が100戸供給する予定である。

特に, 復興住宅の供給のために新たに特優貨住 宅に取り組んだのは，宝塚市，川西市，芦屋市で ある。既に特優賃制度を取り上げている市では, 復興住宅供給促進のために建設基準を緩和してお り，神戸市では敷地規模 $300 \mathrm{~m}^{2}$ 以上を $200 \mathrm{~m}^{2}$ 以上に， 
〈表 1$\rangle$

特優賃事業の概要

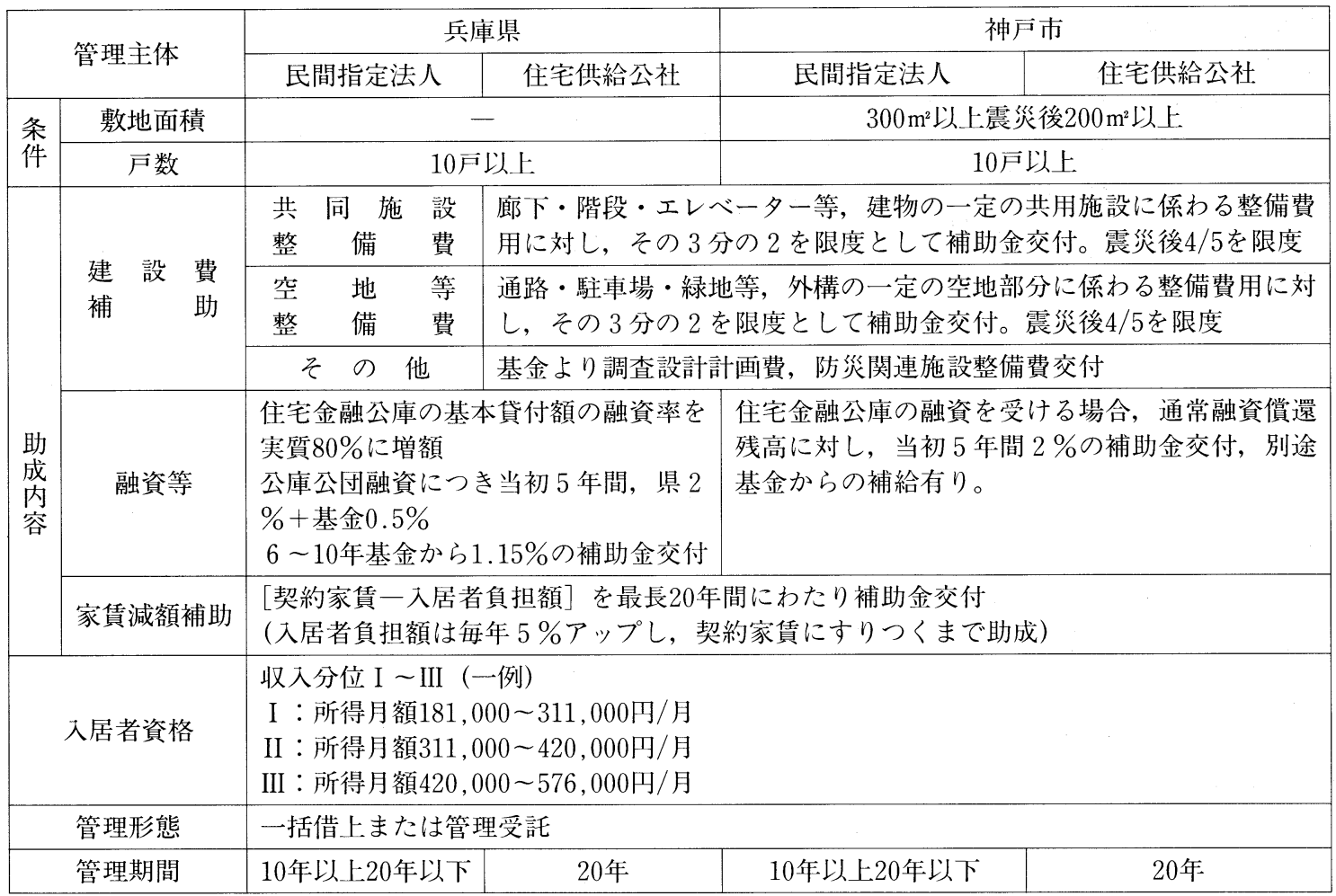

*契約家賃は相場家賃を上限とし，家顀鑑定に基づいて行政の承認を受ける必要がある。

*入居負担額は，収入分位をもとに行政が定める。

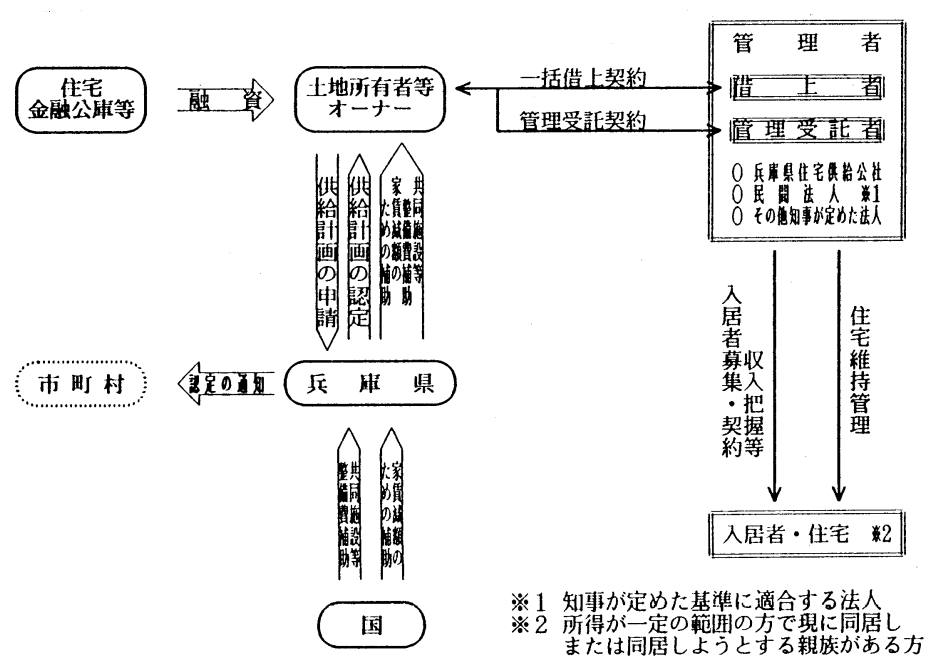

西宮市, 芦屋市では敷地規模 $500 \mathrm{~m}^{2}$ 以上 を $200 \mathrm{~m}^{2}$ 以上に, 総戸数は, 西宮市, 芦 屋市では10戸以上を 5 戸以上に建設基 準を引き下げている。

なお, 平成 9 年 8 月現在にて, 各市 の特優賃住宅の認定戸数は, 神戸市が 3,744戸，西宮市が484戸，伊丹市が88 戸，宝塚市が258戸，川西市が109戸， 尼崎市が512戸，芦屋市が149戸である。 伊丹市と芦屋市は募集を現在中止し ている。

神戸市は, 通常の特優賃住宅と, 更 に建設基準を緩和した特目賃住宅をあ わせ，7,700户供給する予定であるが， 〈図A〉 その内 5,800 户が認定済みである。 
〈表 2-1〉 自治体別の特定優良賃貨住宅の制度比較

\begin{tabular}{|c|c|c|c|c|c|}
\hline & 国の制度 & 兵庫県 & 神戸市 & 伊丹市 \\
\hline \multicolumn{2}{|l|}{ トピックス } & & $\begin{array}{l}\text { 震災後、従来制度を「被災者 } \\
\text { 向け」として条件を緩和した } \\
\text { 制度のみで㐞集中（H } 9 \text { ま } \\
\text { で) } \\
\text { 家賃について県単独の補助と } \\
\text { して、住戸規模の拡大による } \\
\text { 入居者負担額の増叭分の } 1 / 2 \\
\text { を軽堿している }\end{array}$ & $\begin{array}{l}\text { 特優賃の条件をさらに緩和し } \\
\text { た民間借上賃贷住宅（民借 } \\
\text { 貨)の制度も開始 } \\
\text { 管理手法としては借上 } 50 \% \text { 、 } \\
\text { 複合 } 25 \% 、 \text { 管理受託 } 25 \% \text { 程 } \\
\text { 度の割恰 }\end{array}$ & $\begin{array}{l}\text { 復興3ケ年で } 100 \text { 戸 } \\
\text { の目標のうち H7度 } \\
\text { で } 88 \text { 戸クリアした } \\
\text { ため、現在受付を凍 } \\
\text { 結している } \\
\text { 県の供給分もあり、 } \\
\text { 供給過多の状况 }\end{array}$ \\
\hline \multicolumn{2}{|l|}{ 管理主体 } & & $\begin{array}{l}\text { 県住宅供給公社 } \\
\text { 民間指定法人 }\end{array}$ & $\begin{array}{l}\text { 市住宅供給公社 } \\
\text { 民間指定法人 }\end{array}$ & 伊丹市都市整㣁公社 \\
\hline \multicolumn{2}{|c|}{ 管理手法·期間 } & $\begin{array}{l}\text { 管理の委託等 } \\
10 \text { 年以上 }\end{array}$ & $\begin{array}{l}\text { 一括借上型 } \\
\text { 複合型(借上の後管理受託) } \\
\text { 管理受託型 } \\
10 \text { 年以上(実積としては } 20 \text { 年 } \\
\text { 間) }\end{array}$ & $\begin{array}{l}\text { 一括徣上型 } \\
\text { 複合型(県と同じ) } \\
\text { 管理受託型 } \\
20 \text { 年間 }\end{array}$ & $\begin{array}{l}\text { 一括借上型 } \\
20 \text { 年間 }\end{array}$ \\
\hline \multirow[t]{6}{*}{ 建設基淮 } & 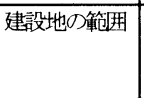 & & $\begin{array}{l}\text { 震災激甚地域または知事が特 } \\
\text { に認める地域 (従来は県内全 } \\
\text { 域の原涀惟居系地域) }\end{array}$ & 管理の方法により差異あり & $\begin{array}{l}\text { 工業地域、工業専用 } \\
\text { 地域を除く }\end{array}$ \\
\hline & 敷地規模 & & $200 \mathrm{~m}^{2}$ 以上 & $300 \mathrm{~m}^{2}$ 以上 (200 $\mathrm{m}^{2}$ 以上) & $500 \mathrm{~m}^{2}$ 以上 \\
\hline & 総戸数 & 10 戸以上 & 5 戸以上 & 原則 10 戸以上 & 10 戸以上 \\
\hline & その他 & & $\begin{array}{l}\text { 福祉のまちづくり条例に適合 } \\
\text { 駐車場を公庫の基淮以上確保 }\end{array}$ & $\begin{array}{l}\text { (1-指定建゚゚レ南)+1/10 以上の } \\
\text { 空地確保 }\end{array}$ & $\begin{array}{l}\text { 駐車場 100\%確保 } \\
\text { 公団建設基淮+特優 } \\
\text { 賃基淮 }\end{array}$ \\
\hline & 住戸専有面積 & $50 \mathrm{~m}^{2}$ 以上 $125 \mathrm{~m}^{2}$ 以下 & $\begin{array}{l}50 \mathrm{~m}^{2} \text { 以上 } 125 \mathrm{~m}^{2} \text { 以下 } \\
\text { 平均専有を概ね } 65 \mathrm{~m}^{2} \text { 以上と } \\
\text { する } \\
\text { (従来は } 75 \mathrm{~m}^{2} \text { 以上の住戸を } 2 \\
33 \text { 以上とする) } \\
\end{array}$ & $\begin{array}{l}50 \mathrm{~m}^{2} \text { 以上 } 125 \mathrm{~m}^{2} \text { 以下 } \\
\text { 公庫融資利用の場合は } 55 \mathrm{~m}^{2} \\
\text { 以上 } \\
\text { 西区と北区の準耐火は原則平 } \\
\text { 均 } 65 \mathrm{~m}^{2} \text { 以上 }\end{array}$ & $\begin{array}{l}60 \mathrm{~m}^{2} \text { 以上 } 125 \mathrm{~m}^{2} \text { 以 } \\
\text { 下 } \\
\text { 平均 } 65 \mathrm{~m}^{2} \text { 以上 }\end{array}$ \\
\hline & 間取り等 & & 3LDK 標準 & $2 \mathrm{DK}$ 以上 & $\begin{array}{l}\text { 2DK 以上、3LDK } \\
\text { 標準 }\end{array}$ \\
\hline \multirow[t]{4}{*}{ 建設費補助 } & $\begin{array}{l}\text { 共同施設等整 } \\
\text { 備費 }\end{array}$ & $\begin{array}{l}\text { 管理期間 } 20 \text { 年以上の場合 } \\
\text { 国 } 1 / 3+\text { 自治体 } 1 / 3=2 \\
/ 3 \\
\end{array}$ & $\begin{array}{l}\text { 国 } 2 / 5+\text { +県 } 2 / 5=4 / 5 \text { (従 } \\
\text { 来注国の制度通り) }\end{array}$ & 国 $2 / 5+\frac{1}{1} 2 / 5=4 / 5$ & $\begin{array}{l}\text { 国 } 2 / 5+\frac{\hbar}{巾} 2 / 5=4 \\
/ 5\end{array}$ \\
\hline & 空地等整備費 & $\begin{array}{l}\text { 国 } 1 / 3+\text { 自治体 } 1 / 3=2 / \\
3\end{array}$ & $\begin{array}{l}\text { 国 } 2 / 5+\text { 県 } 2 / 5=4 / 5 \text { (従 } \\
\text { 来垷の制度通り) }\end{array}$ & 国 $2 / 5+\frac{\hbar}{巾} 2 / 5=4 / 5$ & $\begin{array}{l}\text { 国 } 2 / 5+\text { 市 } 2 / 5=4 \\
/ 5\end{array}$ \\
\hline & $\begin{array}{l}\text { 地域関車施設 } \\
\text { 整備費 }\end{array}$ & $\begin{array}{l}\text { 道路、公園等の地域関軽施設 } \\
\text { (用地費含む) 国·自治体で計 } \\
1 / 3 \\
\end{array}$ & $\begin{array}{l}\text { 定住関連施設整備費として } \\
\text { 国・県より計 } 1 / 3\end{array}$ & $\begin{array}{l}\text { 定住関連施設整備費として } \\
\text { 国・県より計 } 1 / 3\end{array}$ & \\
\hline & その他 & $\begin{array}{l}\text { 再開発関連(調査設計計画費、 } \\
\text { 土地整備費) } 2 / 3\end{array}$ & $\begin{array}{l}\text { 基金より調査設計計画費 (限 } \\
\text { 度額 } 200 \text { 千月/户)、防炎関 } \\
\text { 連施設整備費 (限度額 : 共同 } \\
\text { 施設整備費の } 1 / 5 \\
\text { 県单独補助 : 住戸規模の抎大 } \\
\text { による入居者負担額の増加分 } \\
\text { の } 1 / 2 \text { を軽城) } \\
\end{array}$ & $\begin{array}{l}\text { 基金より調査設計計画費（限 } \\
\text { 度額 } 200 \text { 千円 } / \text { 学)、防災関 } \\
\text { 連施設整備費 (限度額 : 共同 } \\
\text { 施設整備費の } 1 / 5 \text { ) }\end{array}$ & $\begin{array}{l}\text { 基金より調査設計計 } \\
\text { 画費 (限度額 } 200 \text { 千 } \\
\text { 円 } / \text { 戸)、防災関連 } \\
\text { 施設整備費 (限度 } \\
\text { 額 : 共同施設整備費 } \\
\text { の } 1 / 5 \text { ) }\end{array}$ \\
\hline \multirow[t]{2}{*}{ 融資等 } & $\begin{array}{l}\text { 公庫融疼の利 } \\
\text { 用 }\end{array}$ & & $\begin{array}{l}\text { 住宅金融公庫の基本貸付額の } \\
\text { 融資率をを実質 } 80 \% \text { 増額 }\end{array}$ & $\begin{array}{l}\text { 公庫通常融資を（建設費一補 } \\
\text { 助金）の8 割 }\end{array}$ & $\begin{array}{l}\text { 公団の民㑯制度を利 } \\
\text { 用 (建設費·設計費 } \\
\text { の } 100 \% \text { 利用可) } \\
\end{array}$ \\
\hline & 利子補榙 & $\begin{array}{l}\text { 住宅金融公庫等の融資にあた } \\
\text { っての配虑. }\end{array}$ & $\begin{array}{l}\text { 公車につき当初 } 5 \text { 年間県 } 2.0 \% \\
+ \text { +基金 } 0.5 \% \quad 6 \% \text { 年 } \\
\text { 金から } 1.15 \% \text { (上限) } \\
\text { 公団隔蠀についてもあり }\end{array}$ & $\begin{array}{l}\text { 公庫・公団の残高に対し、当 } \\
\text { 初 } 5 \text { 年間 } 2 \% \\
\text { 別に基金からの補給あり }\end{array}$ & なし \\
\hline \multicolumn{2}{|l|}{ 備考・その他 } & & 復興3 万年 5700 F & 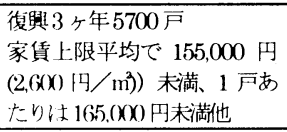 & 復興 3 ヶ年 100 戸 \\
\hline
\end{tabular}


〈表 2-2〉 自治体別の特定優良賃貸住宅の制度比較

\begin{tabular}{|c|c|c|c|c|c|c|}
\hline \multicolumn{2}{|l|}{ 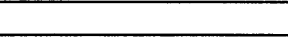 } & 西宮市 & 宝塚市 & 川西市 & 尼崎市 & 芦屋市 \\
\hline \multicolumn{2}{|l|}{ トピツクス } & $\begin{array}{l}\text { 管理主体の都市整備公 } \\
\text { 社は、管理方法を一括 } \\
\text { 借上から、今後供給計 } \\
\text { 画を認定する団地につ } \\
\text { いては、管理受託に切 } \\
\text { り替える }\end{array}$ & $\begin{array}{l}\text { 被災者向けとして始め } \\
\text { ている。般制度とし } \\
\text { て継続するかか方針は } \\
\text { 未定 } \\
\text { H8 から実働、7 団地 } \\
126 \text { 戸を諚済み }\end{array}$ & $\begin{array}{l}\text { もともと賃貸住宅の少な } \\
\text { い地域。若年人口の市内 } \\
\text { 定着のため、積極的に取 } \\
\text { り組みを開始したところ }\end{array}$ & $\begin{array}{l}\text { 市事業として建設分 } \\
\text { を県公社に管理を委 } \\
\text { 託している }\end{array}$ & $\begin{array}{l}\text { 管理主体としての都 } \\
\text { 市整備公社がH } 9 \text { に } \\
\text { 設立される } \\
\text { すでに } 149 \text { 戸認定 } \\
\text { す済みで、H8分は契 } \\
\text { 約時期的に間に合わ } \\
\text { ないので新規の受付 } \\
\text { 止めている。 }\end{array}$ \\
\hline \multicolumn{2}{|l|}{ 管理主体 } & $\begin{array}{l}\text { 西宮市都市整㣁公社 } \\
\text { 民間指定法人 }\end{array}$ & $\begin{array}{l}\text { 民間指定法人 (県の指 } \\
\text { 定法人と同じ) }\end{array}$ & 川西市都市整備公社 & 兵庫県住宅供給公社 & 芦屋市都市整備公社 \\
\hline \multicolumn{2}{|c|}{ 管理手法·期間 } & $\begin{array}{l}\text { 管理受託(従来は一括借 } \\
\text { 上) } \\
20 \text { 年間 }\end{array}$ & $\begin{array}{l}\text { 管理受託（一部借上も } \\
\text { あり） } \\
20 \text { 年間 }\end{array}$ & $\begin{array}{l}\text { 一括借上 } \\
20 \text { 年間 }\end{array}$ & $\begin{array}{l}\text { 一括借上 } \\
20 \text { 年間 }\end{array}$ & $\begin{array}{l}\text { 一括借上 } \\
20 \text { 年間 } \\
\text { 今後の管理力法につ } \\
\text { いては検討中 }\end{array}$ \\
\hline \multirow[t]{6}{*}{ 建設基淮 } & 建設地の範囲 & $\begin{array}{l}\text { 原則住居系の用途地域 } \\
\text { 下水道処理区域内 }\end{array}$ & $\begin{array}{l}\text { 原則住居系の用途地域 } \\
\text { 下水道処理区域内 }\end{array}$ & $\begin{array}{l}\text { 原則隹居系の用途地域 } \\
\text { 下水道処理区域内 } \\
\text { 所有地のみ }\end{array}$ & 所有地のみ & \\
\hline & 敷地規模 & $\begin{array}{l}500 \mathrm{~m}^{2} \text { 以上 }\left(200 \mathrm{~m}^{2} \text { 以 }\right. \\
\text { 上) }\end{array}$ & & $500 \mathrm{~m}^{2}$ 以上 & & $\begin{array}{l}500 \mathrm{~m}^{2} \text { 以上 }\left(200 \mathrm{~m}^{2}\right. \\
\text { 以上) }\end{array}$ \\
\hline & 総戸数 & 10 戸以上 (5 戸以上) & 10 戸以上 & 10 戸以上 & 10 戸以上 & 10戸以上(5戸以上) \\
\hline & その他 & 市の建設基淮あり & 県の基淮と同じ & $\begin{array}{l}3 \text { 階以上 駐車場 } 80 \% \text { 以 } \\
\text { 上(1-指定建-゚萃) }+1 / 10 \\
\text { 以上の空地確保 }\end{array}$ & $\begin{array}{l}\text { EV 設置 駐車場 } \\
80 \% \text { 以上 } \\
\text { 高齢化対応設備 }\end{array}$ & $\begin{array}{l}\text { 市の基淮あり(県の } \\
\text { 福祉条例含む) } \\
\text { 駐車場 } 80 \% \text { 以上 }\end{array}$ \\
\hline & 住戸専有面積 & $\begin{array}{l}60 \mathrm{~m}^{2} \text { 以上 } 125 \mathrm{~m}^{2} \text { 以下 } \\
\text { 平均 } 70 \mathrm{~m}^{2} \text { 以上 }\end{array}$ & $\begin{array}{l}50 \mathrm{~m}^{2} \text { 以上 } 125 \mathrm{~m}^{2} \text { 以下 } \\
\text { 平均概水 } 265 \mathrm{~m}^{2}\end{array}$ & $\begin{array}{l}50 \mathrm{~m}^{2} \text { 以上 } 125 \mathrm{~m}^{2} \text { 以下 } \\
\text { 平均 } 65 \mathrm{~m}^{2} \text { 以上 }\end{array}$ & $65 \mathrm{~m}^{2}$ 以上 $125 \mathrm{~m}^{2}$ 以下 & $\begin{array}{l}60 \mathrm{~m}^{2} \text { 以上 } 125 \mathrm{~m}^{2} \text { 以 } \\
\text { 下 } \\
\text { 平均 } 65 \mathrm{~m}^{2} \text { 以上 } \\
\text { 別に物置 } 2 \mathrm{~m}^{2} / \text { 戸を } \\
\text { 住戸外に設ける }\end{array}$ \\
\hline & 間取り等 & & 県の基淮と同じ & 4DK、3 DK標準 & & $\begin{array}{l}\text { 独立した } 2 \text { 就寝室 }(9 \\
\mathrm{m}^{2} \text { 以上と } 6.5 \mathrm{~m}^{2} \text { 以 } \\
\text { 上) 以上 }\end{array}$ \\
\hline \multirow[t]{4}{*}{ 建設費補助 } & $\begin{array}{l}\text { 共同施設等整 } \\
\text { 備費 }\end{array}$ & $\begin{array}{l}\text { 国 } 2 / 5+\frac{1}{1} 2 / 5=4 / \\
5 \\
\text { (今後事業受付する団地 } \\
\text { について、従来通り } \\
\text { の } 2 / 3 \text { 補助に切り替 } \\
\text { えて募集中) }\end{array}$ & 国 $2 / 5+$ 市 $2 / 5=4$ & $\begin{array}{l}\text { 国と本で } 2 / 3+\text { +基金上 } \\
\text { りの補助 }\end{array}$ & $\begin{array}{l}\text { 国と市で2/3+基金 } \\
\text { よりの補助で } 4 / 5\end{array}$ & $\begin{array}{l}\text { 国と市で } 2 / 3+\text { 基 } \\
\text { 金よりの補助 }\end{array}$ \\
\hline & 空地等整備費 & $\begin{array}{l}\text { 国 } 2 / 5+\text { 市 } 2 / 5=4 / \\
5 \text { (同上) }\end{array}$ & $\begin{array}{l}\text { 国 } 2 / 5+\text { 市 } 2 / 5=4 \\
/ 5\end{array}$ & $\begin{array}{l}\text { 国と市で } 2 / 3+\text { 基金よ } \\
\text { りの補助 }\end{array}$ & $\begin{array}{l}\text { 国と市で } 2 / 3+\text { 基金 } \\
\text { よりの補助 }\end{array}$ & $\begin{array}{l}\text { 国と市で } 2 / 3+\text { 基 } \\
\text { 金よりの補助 }\end{array}$ \\
\hline & $\begin{array}{l}\text { 地域関連施設 } \\
\text { 整備費 }\end{array}$ & & & & & \\
\hline & その他 & $\begin{array}{l}\text { 被災者向けは } \\
\text { 基金より調査設計計画 } \\
\text { 費、防災関連施設整備 } \\
\text { 費の補助あり }\end{array}$ & $\begin{array}{l}\text { 基金より調査設計計画 } \\
\text { 費 (限度額 } 200 \text { 千円 } \\
\text { 兯)、防災関連施設整 } \\
\text { 備費 (限度額 : 共同施 } \\
\text { 設整備費の } 1 / 5 \text { ) }\end{array}$ & $\begin{array}{l}\text { 基金より調査設計計画 } \\
\text { 費、防災関連施設整備費 } \\
\text { の補助あり } \\
\end{array}$ & & $\begin{array}{l}\text { 基金より調查設計計 } \\
\text { 画費（限度額 } 200 \\
\text { 千円／戸)、防災関 } \\
\text { 連施設整備費の補助 } \\
\text { あり }\end{array}$ \\
\hline \multirow[t]{2}{*}{ 融資等 } & $\begin{array}{l}\text { 公庫融資の利 } \\
\text { 用 }\end{array}$ & & $\begin{array}{l}\text { 住宅金融公庫の基本貸 } \\
\text { 付額の融資率を実質 } \\
80 \% \text { 増額 } \\
\end{array}$ & $\begin{array}{l}\text { 住宅金融公庫の基本貸付 } \\
\text { 額の融凟率を実質 } 80 \% \text { に } \\
\text { 堌額 } \\
\end{array}$ & $\begin{array}{l}\text { 住宅金融公庫の基本 } \\
\text { 貸付額の融資率を実 } \\
\text { 質 } 80 \% \text { に増額 }\end{array}$ & $\begin{array}{l}\text { 公讨の民任制度を利 } \\
\text { 用 (建設費·設計費 } \\
\text { の } 100 \% \text { 利用可) }\end{array}$ \\
\hline & 利子補給 & $\begin{array}{l}\text { 公庫、公四ともに利子 } \\
\text { 補秴あり }\end{array}$ & $\begin{array}{l}\text { 公庫、公団ともに利子 } \\
\text { 補給あり }\end{array}$ & $\begin{array}{l}\text { 公庫・民賃の残高に対 } \\
\text { し、当初 } 5 \text { 年間 } 2 \% \\
\text { 基金加当初 } 10 \text { 年間利 } \\
\text { 子補給あり }\end{array}$ & $\begin{array}{l}\text { 公庫の残高に対し、 } \\
\text { 当初 } 5 \text { 年間 } 2 \%\end{array}$ & $\begin{array}{l}\text { 当初 } 5 \text { 年間 } 2 \% \text { 、以 } \\
\text { 後 } 10 \text { 年目まで基金 } \\
\text { からら補給あり }\end{array}$ \\
\hline \multicolumn{2}{|c|}{ 備考·その他 } & 復興 3 ヶ年 1300 戸 & 復興3 年 350 戸 & $\begin{array}{l}\text { 家賃上限 } 13 \text { 万円未満 } \\
\text { 復興 } 3 \text { ケ年 } 100 \text { 户 }\end{array}$ & 復興 3 ヶ年 500 戸 & $\begin{array}{l}\text { 家賃上限 } 20 \text { 万円末 } \\
\text { 満 } \\
\text { 復興 } 3 \text { ヶ年 } 300 \text { 戸 }\end{array}$ \\
\hline
\end{tabular}


ただし, 供給済みの特優賃住宅の空室率が, 6.7 $\% の う え ，$ 新規募集の応募者倍率も落ちてくる等， 賃貸市場環境は厳しい状態である。

\section{4. 特定優良貨貸住宅制度の問題点の調査}

\section{(1) 自治体ヒアリング結果}

各自治体・公社にヒアリング調査することに より，供給側の目標達成率と現時点での問題点を 明らかにする。

兵 庫 県

平成 5 年は県公社のみ。平成 6 年から民間指定 法人を開始した。(平成 6 年の認定 14 户)。

認定のための憲查会は平成 6 年までは年 1 〜 2 回だったが, 平成 7 年は年14回審査し，県 の枠 6,200 戸のうち 8 割がたを達成した。平成 8 年 9 月まで月 1 回の審查で地域を限定して 受付する。(伊丹, 川西, 宝塚, 神戸市西・北区 はストップ)。平成 9 年からは年 $1 \sim 2$ 回審査 の予定である。また立地条件としては駅徒歩 10 分圈内の土地を選別する。

建設の相談は多いが辞退も多く, 辞退する理由 は, (1)周辺近隣対策の困難(2)相続がらみで子世 代との調整の不調(3)需要状況についての不安, があげられる。

平成 9 年 8 月現在で, 県・県市分 9,398 户認定し た。

兵庫県住宅供給公社

契約家顀の見直しはまだ行っていない。

当初の計算上の収支と, 実際に管理開始した時 点での収支の乘離に問題がある。

神戸市住宅供給公社

平成 8 年九月以降募集の応募倍率は悪化した。 年 2,000 人 ( 1 回 500 人 $\times$ 年 4 回) 程度の申込へ 一スは，震災後も変わっていない。

入居済住宅については，1 カ月 30 户程度の退去 がある。退去理由としてはその $60 \%$ が分譲住宅 (マンション)を購入するためである。特優貨住 宅は年 $5 \%$ で家賃が上昇するため, 家賃が 10 万
円を超えたとき，利用者負担がきつい。空室の 入居率は $30 \%$ 程度である。民間指定法人 (18社) は, 公社が駅から10分程度の立地で供給してい ることから競争力に劣り, 入居率は不調であ る。年 $5 \%$ の家賃アップが特優賃住宅のネック なので, 当初家貨をどう下げるかに知恵を絞る 必要がある。

伊丹市

「特定借上・買取貨貸住宅制度」* (平成 7 年の みの制度)で, 災害公営住宅として 4 団地42戸 を認定した。うち 3 団地は特優賃との合筑であ る。

*特定借上・買取賃貸住宅

大臣承認。敷地 $400 \mathrm{~m}^{2}$ 以上。各住戸は $40 \mathrm{~m}^{2}$ 以 上 $50 \mathrm{~m}^{2}$ 以下, $2 \mathrm{DK}$ 以上。一括借上 20 年間。共 同施設等整備費 ・ 空地等整備費補助 $4 / 5$ 。 特優賃の空家は募集して一応全部埋まる。 宅地化農地が多かったのが供給の多さにつな がり、復興 3 力年で 100 戸の目標は, 平成 7 年度 だけで88戸達成した。県の特優賃住宅の供給も あるため，供給過多の傾向にある。

西宮 市

平成 6 年に事業開始し， 2 団地を認定した。平 成 7 年 8 年で 426 户供給した。平成 9 年 8 月 現在で，20団地484戸認定済である。

入居済みの 1 団地 (15戸) は, 応募倍率 7 倍で全 部被災者で理まった。

事業者としては, 認定申請から実際の入居まで 1.5 2 年あり, この間の家賃変動(主として家 貢下落) が問題。農地の転用が半分程度あり, こ れらの地主は損をしなかったらいいという考 えでトラブルは少ないが, これ以外は震災後の 駆け込みであることが多く, 近隣対策に十分時 間をかけられなかったりしているため,トラブ ルのたねになっている。

入居者の反応としては, あくまで民間オーナー の住宅であるので, 年 $5 \%$ の家賃上昇で躊踷し ている。被災者の実態としては, 公営住宅入居 
希望者の割合が増えている。

宝 塚 市

平成 7 年11月に特優賃住宅の供給のための要

綱ができる。

平成 8 年は 7 団地126戸を供給認定し, これら は，平成 9 年度中に完成する予定である。うち 1 団地のみ一括借上をした。1 団地は45戸の規 模, 他は概ね11〜19戸で全体的に規模としては 20 户程度までの小振な夕イプが多い。土地所有 者は個人で農地転用がほとんどである。平均専 有面積は65～70 $\mathrm{m}^{2}$ である。平成 9 年 8 月現在で 9 団地258戸認定済みである。

川西市

平成10年 3 月までに 14 団地を募集することで, 復興 3 力年の 500 户供給目標をクリアできる。 震災後募集の 3 団地 $(92$ 戸) までは被災者で満 室となった。

平成 9 年 8 月現在で 5 団地 109 户認定済みであ る。

\section{尼崎市}

平成10年 3 月までに 14 団地を募集することで, 復興 3 力年の 500 户供給目標をクリアできる。 震災後募集の 3 団地 (92户) までは被災者で満 室となった。

平成 9 年 8 月現在で, 17 団地512戸認定済みで ある。

\section{芦屋市}

平成 7 年 10 月にスタート。仮設入居者約 $200 世$ 帯の解消が目的であったが, 平成 8 年 12 月募集 分については, 市内の全・半壊 (焼)の被災者 は, 15户の募集に対する有効応募件数35件のう ち 10 件 (うち仮設入居者 3 件)にすぎなかった。 被災者向けに民間賃貸住宅の家貨補助が平成 11年まであるため, 現状では特優賃住宅の家貨 補助と遜色ない。公団民賃制度の審查の厳しさ も供給のネックとなっている。 平成 9 年 8 月現在で, 7 団地149戸認定済みで ある。

\section{(2) 特優賃制度の問題点}

以上のヒアリング調査の結果，特優顀制度の問 題点を列挙すると以下の如くあらわせる。

(1)入居者負担の年 $5 \%$ \%ップ

一般的な市場家貨の上昇率とはかけ離れ ている。

○現状では, 入居者負担が市場家貨にすり つくのに「5 年程度」と指摘するところが 多い。

具体的には

○入居希望者の中には，特優貨といっても民 間の住宅に変わりはないと考え，その上毎 年 $5 \%$ 家賃が上がるということで，入居を 思いとどまる人がいる。

○市場家賃とすりついても収入制限の枠がは ずれないので，入居できる人がいるか奬念 される。

○入居者負担が月 10 万円を超えると, 退去す る人がみられる。

○分譲マンション取得層と競合してしまう。

○年 $5 \%$ の家貨アップが仕方ない状況では， 当初の契約家賃をどう下げるかに知恵を絞 るしかない。

○家貨補助のうち，国の負担部分は変わらな くていいから，自治体の負担分は「自治」 にまかせてほしい。

(2)敷金 3 力月の問題

○ 3 力月でなく, 5 - 6 力月欲しい。

○実際に退去の際にメンテナンス費用が敷金 を上回ったケースあり，このケースではオ 一ナーが費用負担した。

○修繥費の負担区分を, 専有部分(入居者対 オーナー), 共用部分 (共益費対オーナー)ご とに提示しているところもある。

長期間計画修繕については，オーナーに 提示はしているが強制はしないというとこ ろもある。

(3)入居開始後 2 年が経過した物件の契約家䍹の 
見直し

○改定したところはない。上げないととも に，下げてもいない。

○空室が問題になるほどにならないかぎりは, 市場の動きを反映させる必要はない，との 意見もある。

(4)計画から管理開始までの期間の長さ

○認定申請から実際の入居まで1.5年から 2 年程度かかり，この間の家賃変動から事 業収支がくるうケースは多い。

○住宅金融公庫の審査にも時間がかかる。

(5)その他

○事業主が事業を断念する理由 近隣対策が困難, 相続がらみの場合の子 世代との調整の不調, 需要状況についての 不安などがあげられる。

○入居者募集時期が限られるため, 賃貸の 需要時期とマッチしない。また空室の補充 をすぐに行えない。

空室については, 待機者募集を行ってい るところは多い。

○その他の家貨補助との関係 阪神大震災の被災地では，民間賃貸住宅 家賃に対しても補助がある。

補助額は平成 $8 \sim 9$ 年度は家賃の $1 / 2(3$ 万円まで)，10年度は $1 / 3$ ( 2 万円まで)， 11 年度は $1 / 6$ ( 1 万円まで)。

○特優賃住宅の出やすいエリアでの供給の 集中

伊丹市には「特優賃村」と呼ばれる地域 もある。

兵庫県分は，伊丹・川西・宝塚・神戸市 西区・北区での事業の申込受付はストップ している。

○共益費が周辺相場より割高になる傾向が ある

共用施設整備に補助が出るため，周辺一 般賃貸住宅に比しグレードが高くなってい
る。このことが共益費を引き上げることに なり，入居者の負担を増している。

\section{(3) 入居申し込み者アンケート調査結果}

民間指定法人が管理受託した15棟の特優貨住宅 申込者のプロフィールについてアンケートした結 果を, 以下の〈表 3 〉の如くまとめた。これによ ると, 特優賃住宅の入居者は, 年収 400 万円台の 20 代の会社員が最も多く，入居者数は 2 人が第 1 位 であることから夫婦で住まうものと思われる。

転居理由の第 1 位が, 「結婚」であるので, 新婚 世帯が多いものと推定される。

申込理由の第 1 位は, 「補助がある」が飛びぬけ て高い。

入居者の以前の住宅は家賃 10 万円未満の $2 \mathrm{LDK}$ の民間賃貸住宅が多く，その住んでいた期間は， 5 年末満である。

\section{（4）特優貨住宅が民間貨貸住宅家貨等の貨貸借条 件に及ぼす影響}

特優賃住宅供給が民間住宅の貸家経営意欲につ いて,どのような影響を与えたかを不動産業者(主 として貨貸専門)に対し，下記項目でのアンケート 調查を行った。

(1)特優賃住宅の供給状況

(2)主たる供給種別

(3)特優賃住宅以外の新築賃貸住宅の家貨，一時 金に対する影響

(4)特優賃住宅以外の既存貸貸住宅の家賃, 一時 金に対する影響

(5)空室率

6)貨貸住宅経営意欲

(7)賃貸住宅の質の変化

(8)地主からの特優賃住宅の相談

この結果を要約すると, 特優貨住宅の供給が多 いエリアでは，民間賃貸住宅は家賃，一時金を值 下げしている物件(家賃 $\triangle 6 \%$ $\triangle 15 \%$,一時金 $\triangle$ $20 \%$ $\triangle 30 \%)$ があることが確認でき, 特優賃住宅 の影響が伺える。特に家賃の下落率より，一時金 の下落率が高く, 敷金が 3 力月である特優貨住宅 
〈表 3〉

\begin{tabular}{|c|c|}
\hline 職 & 会社員 $86.6 \%$, 公務員 $\quad 6.7 \%$, 自営業 $5.8 \%$, 年金他 $0.9 \%$ \\
\hline 年 & $\begin{array}{l}10 \text { 代 } 0.1 \%, 20 \text { 代 } 46.7 \%, 30 \text { 代 } 35.3 \%, 40 \text { 代 } 9.0 \%, 50 \text { 代 } 6.6 \\
\%, 60 \text { 代以上 } 2.3 \%\end{array}$ \\
\hline 年 & $\begin{array}{l}200 \text { 万台 } 7.7 \%, 300 \text { 万台 } 28.8 \%, 400 \text { 万台 } 35.7 \%, 500 \text { 万台 } 17.0 \\
\%, 600 \text { 万台 } 5.4 \%, 600 \text { 万台超 } 5.3 \% \\
\text { \% }\end{array}$ \\
\hline 居 & 2 人 $55.0 \%, 3$ 人 $27.3 \%, 4$ 人 $14.8 \%, 5$ 人以上 $2.9 \%$ \\
\hline 込 & $\begin{array}{l}\text { 補助がある } 34.9 \% \text { ，負担額が適当 } 9.3 \% \text { ，環境が良い } 4.8 \% \text {, } \\
\text { 間取り } 10.9 \% \text {, 広い } 7.6 \% \text {, 交通便 } 11.4 \% \text {, 職場に近い } 7.6 \\
\% \text {, 実家に近い } 7.2 \% \text {, 利便施設の充実 } 4.3 \%\end{array}$ \\
\hline $\begin{array}{l}\text { 以前の住宅からの } \\
\text { 転 居 理 由 }\end{array}$ & 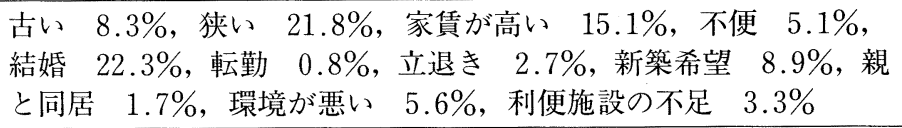 \\
\hline 以前の住宅の形態 & $\begin{array}{l}\text { 公営 } 9.0 \% \text { ，民間賃貸住宅 } 57.1 \% \text { ，社宅 } 3.5 \% \text { ，持家 } 3.2 \% \text {, } \\
\text { 親の家 } 24.7 \% \text { l }\end{array}$ \\
\hline 以前の住宅の家賃 & 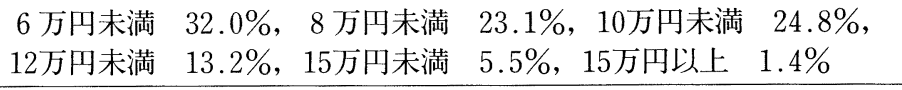 \\
\hline 以前の住宅の間取り & 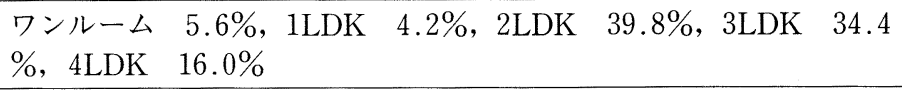 \\
\hline 住んでいた期間 & $\begin{array}{c}1 \text { 年末満 } 7.8 \%, 2 \text { 年末満 } \quad 16.4 \%, 5 \text { 年末満 } 29.5 \%, 10 \text { 年末満 } \\
18.4 \%, 10 \text { 年以上 } 27.9 \%\end{array}$ \\
\hline
\end{tabular}

の一時金に及ぼす影響が特に強いものと思料され る。

また，賃借人側でも家賃より一時金の方が低く なる希望が多いようである。

この他，特優賃住宅へ入居者が転居したために， 民間貨貸住宅の空室が増加したとの回答もよせら れている。

特筆すべきは，特優賃住宅ができたことで，そ の周辺の地域で新たに貨貸住宅を経営する意欲が ある地主が増えたか否かでは, 特優貨住宅の供給 が少なく，家賃，一時金に影響を与えていないエ リアでは，特優賃住宅の経営に意欲がみられるが， 特優賃住宅の供給戸数が多く, かつ賃料, 一時金 の見直しが行われた地域では，賃料，一時金の下 方修正が顕著であるため, 地主の経営意欲を減退 せしめており，貸貸住宅を新たに経営しようとす る地主は減少している。

\section{（5）被災地における特優賃住宅の問題点}

特優賃住宅のシステムは, 賃料は年 $5 \%$ で上昇
していくことが前提であり，オーナーとの契約家 賃は，市場家賃をべースとしている。

このため, 市場家賃が下降すると特優賃住宅の 入居者は, 収入の高い者から早い時期に市場家覒 にすりつき追い越すことになる。

家貨下降の著しい地域では, 新築まもなく空室 が出始め, 再募集をかけても空室がなかなか埋ま らない状況である。

弊社調査の大阪府・阪神間の賃料動向調査では, 新築募集賃料は「ファミリータイプ」は’90年をピ ークに,「ワンルーム」は’93年をピークに，賃料は 上昇から下降に転じた。'96年調査では, 南大阪は 賃料下降が続行しているが，大阪市，北大阪では ファミリータイプは横ばい基調に入った。

ところが，阪神間は，大阪市，北大阪と異なる 動きをしている。即ち, 震災年の’95年は供給量が 激減し，家貨上昇がみられた。

’96年は震災前を上回る供給があり，「ワンルー ム」は震災前より上昇し，「 $2 \mathrm{~K} \sim 2 \mathrm{LDK} 」 「 3 \mathrm{~K}$ 
〈表 4 〉

\begin{tabular}{|c|c|c|c|c|c|c|}
\hline & \multicolumn{3}{|c|}{ 特優賃契約家賃 } & \multicolumn{3}{|c|}{ 民間賃貸住宅市場家賃 } \\
\hline & 平成 8 年 & 平成 9 年 & 変動率 $(\%)$ & 平成 8 年 & 平成 9 年 & 変動率 $(\%)$ \\
\hline 兵 庫 区 & 2,001 & 2,052 & +2.5 & 1,922 & 1,989 & +3.5 \\
\hline 長 田 区 & 2,090 & 1,894 & $\triangle 9.4$ & 1,872 & 1,721 & $\triangle 8.1$ \\
\hline 中 央 区 & 2,139 & 2,225 & +4.0 & 2,197 & 2,500 & - \\
\hline 灘 & 2,327 & 2,240 & $\triangle 3.7$ & 2,350 & 2,240 & $\triangle 4.7$ \\
\hline 東 灘 区 & 2,177 & 2,155 & $\triangle 1.0$ & 2,312 & 2,174 & $\triangle 6.0$ \\
\hline
\end{tabular}

（注 1 ）中央区民間賃貸住宅市場家賃の平成 9 年は，デー夕 1 件で比較不可

（注 2 ）民間賃貸住宅市場家賃事例は，2 K以上を採用

（注３）記載のない区は，特優顀住宅が経年比較できない区である。北区，西区は震災影響がないため不採用。

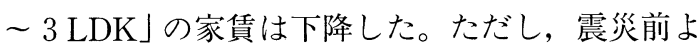
りは，未だ高い水準であった。ところが，'96年後 半から，震災後の新築供給が増加し始めて家賃の 下降がいずれの夕イプも顕著になってきている。

〈表 4 〉は，特優賃契約家賃と民間賃貸住宅市 場家賃の比較表である。

概ね，特優顀も民間賃貸住宅家賃も下落してい る。

平成 9 年後半は, 賃貸住宅の供給増と分譲マン ション購入者がマンションの引渡しを受け貨貸住 宅を退去する需要減から家賃の下落は, 続行する ことが予測される。

また，震災後神戸市全体で約 10 万人，インナー エリアで約 28 万人, 人口が流出していることも需 要減に結びついている。

神戸市住宅供給会社では, 既に入居済みの特優 賃住宅について家賃下落の著しい地域から，契約
家賃の引下げを検討している。

しかしながら，特優賃制度の問題点は，家賃の 適正化で解消できるものではなく，法で定められ た年 $5 \%$ の家賃上昇に問題がある。弊社調查によ る’ 85 年から’ 96 年の 12 年間にわたる住宅貨料の年 間変動率は，「 $2 \mathrm{~K} \sim 2 \mathrm{LDK}$ で+2.6\%，「 $3 \mathrm{~K}$ 〜 3 LDK」で1.6\%であり，実態とかけ離れてい る。

特優顀住宅制度については，その他の問題点も あるが，住宅賃料は，需要が高まれば高くなり， 供給が多くなれば横ばい若しくは下落という地域 の需給バランスによって定まるものであり，この 意味では，家賃の定率上昇を固定化したシステム では，需要者離れをおこすのは必須である。被災 者の生活再建のためにも定率上昇システムは改善 が望ましい。 